\title{
Morphology of fruits, seeds, seedlings and saplings of three species of Macrolobium Schreb. (Leguminosae, Caesalpinioideae) in the Brazilian Amazon floodplain ${ }^{1}$
}

Gildo Vieira Feitoza ${ }^{2,5}$, João Ubiratan Moreira dos Santos ${ }^{3}$, Ely Simone Cajueiro Gurgel ${ }^{2}$ and Denise Maria Trombert Oliveira ${ }^{4}$

Received: 29 August, 2013. Accepted: 26 March, 2014

\begin{abstract}
The evaluation of the post-germination phases of plants allows the recognition of transitional structures that support the relationships among taxa and their establishment. Together with fruit and seeds, seedlings and saplings provide useful characters for identifying many species. This study aimed to describe and characterize the morphology of the fruits, seeds, seedlings and saplings of Macrolobium acaciifolium, M. bifolium and M. pendulum, as well as to evaluate the ecological, taxonomic and phylogenetic value of the structures identified. In this work, the seeds were sown in plastic trays with sterilized sand and sawdust, without pre-germination treatment. The fruits of the three species are woody legumes, dehiscent fruit or indehiscent fruit. The seeds have seed coats with or without venation and variable embryos, with plumules differing among the three species; this trait can be helpful in distinguishing among the species studied. The seedlings are of the cryptocotylar-hypogeal-reserve or phanerocotylar-epigeal-reserve type. Macrolobium bifolium and $M$. pendulum are similar species, differing in only a few characters. These characters have taxonomic value and aid species identification. The characteristics of $M$. pendulum are described here for the first time.
\end{abstract}

Key words: Detarieae, embryo, Fabaceae, plumule, post-germination development

\section{Introduction}

The morphological aspects of the initial stages of plant development have been poorly investigated in various families, principally when compared with the structure of mature vegetative organs. The study of the initial morphology provides knowledge about transitional or ephemeral structures that can supply relevant insights into phylogenetic relationships (Moreira-Coneglian \& Oliveira 2006). Likewise, the morphological characters of fruits and seeds constitute highly reliable criteria for botanical identification, because they normally have little phenotypic plasticity and are therefore good taxonomic characters (Oliveira \& Pereira 1984; Oliveira 1999a). In addition, data about seedlings, fruits and seeds can contribute information that is valuable for analyzing the systematics and ecology of various groups of tropical plants (Garwood 1995).

Morphological studies of fruits, seeds, seedlings and saplings have helped the characterization of several taxonomic groups in Leguminosae. In Caesalpinioideae, details have been presented for Copaifera (Gurgel 2009). In Mi- mosoideae, Calliandra and Mimosa have been evaluated (Parra 1984). In Papilionoideae, there have been studies of Phaseoleae (Baudet 1974); Dalbergieae (Lima 198990); Genisteae (López et al. 1998); Phaseoleae, Sophoreae, Swartzieae and Tephrosieae (Oliveira 2001); Vatairea (Rodrigues \& Tozzi 2007a); the genistoid clade (Rodrigues \& Tozzi 2007b); Acosmium, Guianodendron and Leptolobium (Rodrigues \& Tozzi 2008); and Rhynchosia (Rodrigues et al. 2012). The studies of Duke \& Polhill (1981), Oliveira (1999a) and Gurgel et al. (2012) evaluated various genera within the three subfamilies.

Although Leguminosae is a well-known family, there have been few studies of its representatives in the Amazon, notable exceptions including studies conducted in the Venezuelan Amazon (Ricardi 1996; 1999a; 1999b) and in the Brazilian Amazon (Silva et al. 1988; Vieira et al. 1996; Aguiar \& Mendonça 2000; Gurgel et al. 2002; Ramos \& Ferraz 2008; and Rodrigues et al. 2012). There is also a lack of data on seedlings that occur in specific environments of the Amazon, such as the floodplain forests, where species are subjected to periodic flooding (Silva et al. 1988; Moreira \&

\footnotetext{
${ }^{1}$ Based on the Master's dissertation of the first author

${ }^{2}$ Museu Paraense Emílio Goeldi, Av. Magalhães Barata 376, São Braz, CP 399, 66040-170, Belém, PA, Brazil

${ }^{3}$ Universidade Federal Rural da Amazônia, Instituto de Ciências Agrárias, Belém, PA, Brazil

${ }^{4}$ Universidade Federal de Minas Gerais, Instituto de Ciências Biológicas, Departamento de Botânica, Belo Horizonte, MG, Brazil

${ }^{5}$ Author for correspondence: gdfeitoza@gmail.com
} 
Morphology of fruits, seeds, seedlings and saplings of three species of Macrolobium Schreb.

(Leguminosae, Caesalpinioideae) in the Brazilian Amazon floodplain

Moreira 1996; Gama et al. 2003; Maia et al. 2005; Schöngart et al.2005). Such knowledge is important to protecting and understanding the regeneration of these ecosystems.

Macrolobium Schreb. (Leguminosae, Caesalpinioideae) is currently included in Detarieae s.l. (Bruneau et al. 2000; 2001; Herendeen et al. 2003). The tribe Detarieae s.l., comprises all of the genera included in Detarieae, Cynometreae and Amherstieae (Léonard 1957); in Detarieae and Amherstieae (Cowan \& Polhill 1981); in Detarieae (Polhill 1994); and in Detarieae and Macrolobieae (Breteler 1995), excluding the monotypic genus Umtiza Sim, which occurs in Southern Africa (Herendeen et al. 2003).

Macrolobium comprises approximately 80 species and is strictly distributed in the tropics (De la Estrella et al. 2012). Approximately 40 species occur in Brazil, 15 of which are endemic (Martins-da-Silva \& Lima 2013). Macrolobium is the second most representative genus of Detarieae $s . l$ (Lewis et al., 2005), being used as an ornamental, for timber, to produce fish poison and for lumber in construction (Gama et al. 2003; Mackinder 2005; Felix-da-Silva et al. 2013). The genus is common in the Brazilian Amazon, mostly in the Negro River Basin, where it constitutes one of the dominant floristic elements of floodplain forests (Ducke 1949).

The phylogenetic relationships of Detarieae s.l. were analyzed by Bruneau et al. $(2000 ; 2001)$, on the basis of $\operatorname{trn} \mathrm{L}$ nucleotide sequence data, and by Herendeen et al. (2003), who used morphological data merged with the aligned trnL data. Detarieae s.l. has a pantropical distribution, approximately $58 \%$ of the species being restricted to Africa, including Madagascar, 20\% being endemic in the Neotropics; and $12 \%$ being endemic in tropical Asia (Mackinder 2005). The genus Macrolobium is at the base of the "higher" Detarieae s.l., constituting a group together with species of the genera Brownea Jacq., Browneopsis Huber, Elizabetha Schomb. ex Benth., Paloue Aubl. and Ecuadendron D.A. Neill. (Herendeen et al. 2003). This underscores the statement made by Bruneau et al. (2000): that the Macrolobium group (sensu Cowan \& Polhill 1981) or complex (sensu Léonard 1957) has a complicated history. Bruneau et al. (2000) also stated that the relationships of the Macrolobium group requires a critical evaluation of morphological and anatomical characters in order to examine the possibility of a close affinity between New World Macrolobium and members of the South American Brownea group.

The Environmental Protection Area of Combu Island (EPA of Combu Island), in the state of Pará, Brazil, presents a varied floristic structure and composition (Rodrigues et al. 2006). Macrolobium bifolium (Aubl.) Pers. is native to the Amazon region and has been recorded for the Combu Island EPA (Maúes et al. 2011). Macrolobium acaciifolium (Benth.) Benth. has a wide distribution in Brazil, and M. pendulum Willd. ex Vogel is endemic in the country, occurring in the states of Amazonas, Pará and Maranhão (Martins-da-Silva \& Lima 2013); both species represent new records for the Combu Island EPA.
The present study describes the morphology of fruits, seeds and the post-germination phases of Macrolobium acaciifolium, M. bifolium and $M$. pendulum, aiming to aid the identification of native species of Amazon floodplain forests and to provide a foundation for further phylogenetic and ecological studies involving this complex group.

\section{Material and methods}

Fruits and seeds of Macrolobium acaciifolium, M. bifolium and M. pendulum were collected from natural populations in the Combu Island EPA $\left(48^{\circ} 25^{\prime} \mathrm{W} ; 1^{\circ} 25^{\prime} \mathrm{S}\right)$. The area is entirely constituted of flooded forest (alluvial rain forest) and presents Humic Gleysols, with high percentages of silts and clay and a low percentage of sand (Silva \& Sampaio 1998). According to the Köppen classification system, the climate of the region is type Am, with a mean annual rainfall of $2500 \mathrm{~mm}$ and a mean annual temperature of $27^{\circ} \mathrm{C}$ (Jardim \& Vieira 2001).

Two matrix trees were selected for each Macrolobium species studied. The fruits were collected between January and April 2012, from directly under the trees or with a trimmer. The fruits were packed into polyethylene bags and transported to the Laboratory of Fruit and Seed Morphology of the Museu Paraense Emílio Goeldi for detailed analysis and measurement. Voucher specimens were deposited in the Herbarium of the Museu Paraense Emílio Goeldi, in Belém, Brazil (MG), under the accession numbers MG-204242 (M. acaciifolium), MG-204243 (M. bifolium) and MG204244 (M. pendulum).

Samples (30 fruits and 50 seeds of each species) were randomly collected and analyzed. The dimensions (length, width and thickness) were measured with an UltraTech ${ }^{\text {Tm }}$ digital fractional caliper ( $0.01 \mathrm{~mm}$ accuracy; General Tools, New York, NY, USA). The length was considered the distance from the apex to the base; the width was measured from the dorsal to ventral regions, and the thickness between valves was determined. For observation and illustration of fruits and seeds, we used a stereomicroscope (Motic, SMZ168 series, Vancouver, Canada) and a camera lucida. The terminology was based on Gunn $(1981 ; 1991)$, Barroso et al. (1999) and Oliveira (1999b).

For the description of plumule development, three embryos of each species were selected and samples of the embryo axis were fixed in $2.5 \%$ glutaraldehyde in $0.1 \mathrm{M}$ sodium phosphate buffer $\mathrm{pH} 7.2$ for $24 \mathrm{~h}$. The samples were then dehydrated in a graded ethanol series, dried in a $\mathrm{CO}_{2}$ critical point dryer, sputter-coated with gold (Robards 1978) and analyzed in a scanning electron microscope (1450VP; LEO Electron Microscopy Ltd, Cambridge, UK). The morphology of each plumule was described according to Oliveira (1999b), considering the types undifferentiated, rudimentary, moderately differentiated and well differentiated.

For the post-germination study, 30 seeds of each matrix tree, without pre-germination treatment, were sown in 
plastic trays $(80 \times 40 \times 20 \mathrm{~cm})$ containing sterilized sawdust and sand (1:1) at a depth of $\pm 1 \mathrm{~cm}$, maintained at room temperature and in natural light in a greenhouse (average temperature, $26^{\circ} \mathrm{C}$ ). After the expansion of the second eophyll, the saplings were transplanted to polyethylene bags that were filled with a mixture of sand and vermiculite (1:1), after which they were watered once a day.

We defined the seedling phase as that occurring between the protrusion of the primary root and the full expansion of the eophylls of the first node (sensu Oliveira 2001). Voucher specimens of Macrolobium saplings collected at 40 days after germination were prepared and deposited in MG under the accession numbers MG-204245 (M. acaciifolium), MG-204246 (M. bifolium) and MG-204247 (M. pendulum). Some specimens were preserved in $70 \%$ ethanol to show the different stages of post-germination development.

To describe the morphology of seedlings and saplings, we selected 20 samples of each species and we photographed each sample with a digital camera (FinePix S4500; FUJIFILM do Brazil, São Paulo, Brazil). The structure of the hypocotyl, epicotyl, cotyledons, cataphylls and eophylls was described. The terminology for the seedling morphological types-cryptocotylar-hypogeal-reserve (CHR) and phanerocotylar-epigealreserve (PER) - followed Garwood (1996), and descriptive terms were based on Radford et al. (1974) and Harris \& Harris (2001). We also employed the terminology established by Camargo et al. (2008), describing seedlings according to the unipolar or bipolar emergence of the root and epicotyl. The saplings were evaluated until the complete expansion of the third eophyll, as adopted for other Leguminosae species by Rodrigues \& Tozzi (2008) and Rodrigues et al. (2012).

\section{Results}

The quantitative and qualitative data related to fruits, seeds and seedlings are summarized in Tab. 1 and 2, respectively. The fruits of Macrolobium acaciifolium (Fig. 1 and 2), M. bifolium (Fig. 3 and 4) and M. pendulum (Fig. 5 and 6) are woody legumes, dehiscent fruit or indehiscent fruit (Tab. 2), all of which are subapiculate and substipitate. The funiculus is flattened, and the seeds are transversally disposed (Fig. 2, 4 and 6).

The seeds are brownish and laterally compressed, variable in form (Fig. 7-9, Tab. 2), with or without conspicuous venation; the micropyle is inconspicuous and the hilum is basal and elliptical. The endosperm is absent, and the cotyledons are storage organs that are juxtaposed, symmetric or asymmetric, and plano-convex, the abaxial surface being sinuate or entire (Fig. 7-9, Tab. 2). The embryos are investing, and the embryo axis is straight or oblique, oblong or conical (Fig. 10-12, Tab. 2). Among the three species, plumules vary from well differentiated, to moderately differentiated and undifferentiated (Fig. 13-15).

All of the seeds we tested germinated. The morphological aspects of seedlings and saplings of Macrolobium acaciifolium, M. bifolium and $M$. pendulum can be seen in Fig. 16-21, Fig. 22-29 and Fig. 30-35, respectively. The germination of all species began with the rupture of the seed coat in the hilum-micropyle region and the emergence of the primary root, which is whitish, non-tuberose and cylindrical (Fig. 16, 22 and 30). The hypocotyl is cylindrical or quadrangular (Fig. 28). The seedlings are type CHR (Fig. 16-19) or PER (Fig. 22-26 and 30-33). The emergence of the primary root and epicotyl is unipolar. The vegetative axis is lateral to the cotyledons (Fig. 17) or between them (Fig. 24 and 32). All three species presented an alternate arrangement of the eophylls (Fig. 21, 29 and 35). In all three species, the eophylls of the three first nodes were very similar, occurring as even-pinnate (Fig. 20 and 21) or bifoliolate (Fig. 27, 29 and 35) and variable in form. In young eophylls, we observed pairs of stipules that are axillary, filiform and free between them; the stipules are caducous (Fig. 21 and 29) or persistent (Fig. 35). Nyctinastic movement is observed in all species, in which the leaflets are "forward-folding".

Macrolobium acaciifolium (Benth.) Benth.-The fruit is indehiscent, woody, oblong to oval, flattened, sparsely pilose at the margins, without constrictions, substipitate, with an oblique base, apex obtuse and rounded with a short apiculus (Fig. 1-2). The pericarp is externally shiny and slightly rough, with red-brown to brown dots, and internally spongy and brown. The seed is oblong to elliptical (Fig. 2), laterally compressed (Fig. 7), red-brown, with smooth surface (Fig. 2 and 7), radicular lobe poorly pronounced, without seed appendages; micropyle, lens and raphe inconspicuous. The embryo is cream-colored, with symmetrical storage cotyledons that are sinuate, juxtaposed (Fig. 7) and strongly adhered to each other. There is no endosperm; only residues can be seen around embryo axis, which is conical, two-thirds exposed and oblique to the cotyledons (Fig. 10). The plumule is well differentiated (Fig. 13), and the seedling is type CHR (Fig. 16-20). The germination is unipolar, and the vegetative axis is lateral to the cotyledons (Fig. 17). The hypocotyl is cylindrical, whitish and glabrous. The epicotyl is cylindrical, light green and glabrous. The axillary buds are inconspicuous; the first three eophylls are alternate, even-pinnate, with glabrous pulvini, petioles and rachises. Leaflets are oblong, with oblique bases, retuse to emarginate apices, entire margin; a small pulvinule occurs at the base of each leaflet.

Macrolobium bifolium (Aubl.) Pers.-The fruit is dehiscent, woody, oblong to spatulate, flattened, glabrous, without constrictions, substipitate, with an oblique base, truncate to obtuse apex with a short apiculus (Fig. 3 and 4). The pericarp is externally opaque, reticulate, light brown to brown; internally spongy, cream-colored to brown. The seed is oval to orbicular (Fig. 4), laterally compressed (Fig. 8), light brown, symmetric, with evident seed coat venation; 
Morphology of fruits, seeds, seedlings and saplings of three species of Macrolobium Schreb.

(Leguminosae, Caesalpinioideae) in the Brazilian Amazon floodplain

Table 1. Quantitative data* ${ }^{\star}$ related to samples of fruits $(\mathrm{n}=30)$ and seeds $(\mathrm{n}=50)$ of Macrolobium acaciifolium (Benth.) Benth., Macrolobium bifolium (Aubl.) Pers. and Macrolobium pendulum Willd. ex Vogel.

\begin{tabular}{|c|c|c|c|c|}
\hline Character & Statistic & M. acaciifolium & M. bifolium & M. pendulum \\
\hline \multirow{4}{*}{ Fruit length } & minimum & 50.00 & 91.08 & 64.40 \\
\hline & maximum & 62.00 & 108.10 & 80.79 \\
\hline & average & 55.09 & 100,35 & 73.45 \\
\hline & standard deviation & 3.76 & 5.96 & 6.50 \\
\hline \multirow{4}{*}{ Fruit width } & minimum & 36.00 & 54.55 & 38.00 \\
\hline & maximum & 41.47 & 62.71 & 55.00 \\
\hline & average & 39.14 & 57.63 & 49.43 \\
\hline & standard deviation & 1.82 & 2.94 & 6.14 \\
\hline \multirow{4}{*}{ Fruit thickness } & minimum & 8.00 & 13.15 & 5.00 \\
\hline & maximum & 10.14 & 14.58 & 8.30 \\
\hline & average & 9.31 & 13.95 & 6.51 \\
\hline & standard deviation & 0.70 & 0.51 & 1.17 \\
\hline Seeds per fruit & & 1 & $1(2-3)$ & $1-2$ \\
\hline \multirow{4}{*}{ Seed length } & minimum & 23.25 & 31.18 & 24.38 \\
\hline & maximum & 32.28 & 47.69 & 38.62 \\
\hline & average & 26.51 & 36.66 & 31.79 \\
\hline & standard deviation & 2.53 & 4.97 & 4.59 \\
\hline \multirow{4}{*}{ Seed width } & minimum & 29.66 & 33.86 & 36.80 \\
\hline & maximum & 40.44 & 47.00 & 51.00 \\
\hline & average & 33.14 & 37.31 & 42.71 \\
\hline & standard deviation & 3.04 & 3.97 & 5.30 \\
\hline \multirow{4}{*}{ Seed thickness } & minimum & 4.95 & 4.69 & 4.78 \\
\hline & maximum & 7.18 & 11.40 & 7.30 \\
\hline & average & 5.58 & 7.33 & 5.73 \\
\hline & standard deviation & 0.61 & 1.89 & 0.92 \\
\hline \multirow{4}{*}{ Embryo axis length } & minimum & 3.97 & 8.18 & 3.86 \\
\hline & maximum & 5.48 & 14.28 & 5.72 \\
\hline & average & 2.67 & 11.12 & 4.81 \\
\hline & standard deviation & 0.66 & 2.02 & 0.65 \\
\hline \multirow{4}{*}{ Embryo axis width } & minimum & 1.91 & 2.79 & 2.17 \\
\hline & maximum & 3.26 & 5.38 & 2.76 \\
\hline & average & 1.99 & 3.77 & 2.46 \\
\hline & standard deviation & 0.45 & 0.67 & 0.13 \\
\hline
\end{tabular}

${ }^{*}$ All measurements are expressed in millimeters.

seed appendages are not found, and micropyle, lens and raphe are inconspicuous. The embryo is cream-colored with two plano-convex, storage, symmetrical cotyledons (Fig. 8). The endosperm is absent and the embryo axis is oblong and straight (Fig. 11). The plumule is moderately differentiated (Fig. 14). The seedling is type PER (Fig. 22-26), and germination is unipolar with the vegetative axis between the cotyledons (Fig. 24). The hypocotyl is quadrangular (Fig. 28) and glabrous. The epicotyl is cylindrical, dark-green and glabrous. The axillary buds are inconspicuous. The three first eophylls are alternate (Fig. 26-27 and 29), bifoliolate, with oblong to falcate leaflets (Fig. 27), with oblique bases, acute to acuminate apices and entire margins, showing glabrous pulvini and petioles; a small pulvinule occurs at the base of each leaflet.
Macrolobium pendulum Willd. ex Vogel.-The fruit is dehiscent, woody, D-shaped (Fig. 5), flattened, glabrous, without constrictions, substipitate, with oblique base and obtuse apex (Fig. 5 and 6). The pericarp is externally shiny and smooth, without apparent venation, and dark-brown; internally, it is light brown. The seed is oval to reniform (Fig. 6), laterally compressed (Fig. 9), dark brown and asymmetrical, with evident seed coat venation; without seed appendages; funicular residue is adhered to the hilum region; the micropyle, lens and raphe are inconspicuous. The embryo is light brown with two storage cotyledons, plano-convex and asymmetrical (Fig. 9). The endosperm is absent, and the embryo axis is oblong and straight (Fig. 12). The plumule is undifferentiated (Fig. 15). The seedling is type PER, and the germination is unipolar with the vegetative axis 
Table 2. Qualitative data* ${ }^{\star}$ related to the fruits, seeds, seedlings and saplings of Macrolobium acaciifolium (Benth.) Benth., Macrolobium bifolium (Aubl.) Pers. and Macrolobium pendulum Willd. ex Vogel.

\begin{tabular}{|c|c|c|c|c|}
\hline Component & Character & M. acaciifolium & M. bifolium & M. pendulum \\
\hline \multirow{9}{*}{ Fruits } & Consistence & woody & woody & woody \\
\hline & Dehiscence & indehiscent & dehiscent & dehiscent \\
\hline & Type & indehiscent legume & typical legume & typical legume \\
\hline & Transversal contour & flattened & flattened & flattened \\
\hline & Longitudinal contour & oblong to oval & oblong to spatulate & D-like \\
\hline & Apex & obtuse and rounded & truncate to obtuse & obtuse \\
\hline & Apiculus & subapiculate & subapiculate & subapiculate \\
\hline & Base & oblique & oblique & oblique \\
\hline & Stipe & substipitate & substipitate & substipitate \\
\hline \multirow{17}{*}{ Seeds } & Transversal contour & compressed & compressed & compressed \\
\hline & Longitudinal contour & oblong to elliptical & oval to orbicular & oval to reniform \\
\hline & Seed coat venation & inconspicuous & conspicuous & conspicuous \\
\hline & Micropyle & inconspicuous & inconspicuous & inconspicuous \\
\hline & Hilum & elliptical & elliptical & elliptical \\
\hline & Lens & inconspicuous & inconspicuous & inconspicuous \\
\hline & Raphe & inconspicuous & inconspicuous & inconspicuous \\
\hline & Appendages & absent & absent & absent \\
\hline & Endosperm & absent & absent & absent \\
\hline & Embryo type & investing & investing & investing \\
\hline & $\begin{array}{r}\text { Consistence of the } \\
\text { cotyledons }\end{array}$ & storage & storage & storage \\
\hline & $\begin{array}{r}\text { Cotyledons in cross } \\
\text { section }\end{array}$ & plano-convex & plano-convex & plano-convex \\
\hline & $\begin{array}{r}\text { Symmetry of the } \\
\text { cotyledons }\end{array}$ & symmetric & symmetric & asymmetric \\
\hline & $\begin{array}{r}\text { Abaxial surface of } \\
\text { cotyledons }\end{array}$ & sinuate & entire & entire \\
\hline & Embryo axis position & oblique & straight & straight \\
\hline & Shape of embryo axis & conical & oblong & oblong \\
\hline & Plumule development & well differentiated & moderately differentiated & undifferentiated \\
\hline \multirow{14}{*}{ Seedlings and saplings } & Type & CHR & PER & PER \\
\hline & Hypocotyl shape & cylindrical & quadrangular & cylindrical \\
\hline & $\begin{array}{r}\text { Root and epicotyl } \\
\text { emergence }\end{array}$ & unipolar & unipolar & unipolar \\
\hline & Vegetative axis position & lateral to cotyledons & between cotyledons & between cotyledons \\
\hline & Epicotyl shape & cylindrical & cylindrical & cylindrical \\
\hline & Axillary buds & inconspicuous & inconspicuous & inconspicuous \\
\hline & Eophylls arrangement & alternate & alternate & alternate \\
\hline & Eophylls division & even-pinnate & bifoliolate & bifoliolate \\
\hline & Leaflets shape & oblong & oblong to falcate & oblong to falcate \\
\hline & Leaflets apex & retuse to emarginate & acute to acuminate & obtuse a attenuate \\
\hline & Leaflets base & oblique & oblique & oblique \\
\hline & Leaflets margin & entire & entire & entire \\
\hline & Persistence of stipules & caducous & caducous & persistent \\
\hline & Nyctinasty & "forward-folding" & "forward-folding" & "forward-folding" \\
\hline
\end{tabular}

CHR - cryptocotylar-hypogeal-reserve; PER - phanerocotylar-epigeal-reserve.

*Bolded states are shared by two species; underlined states segregate the three species. 

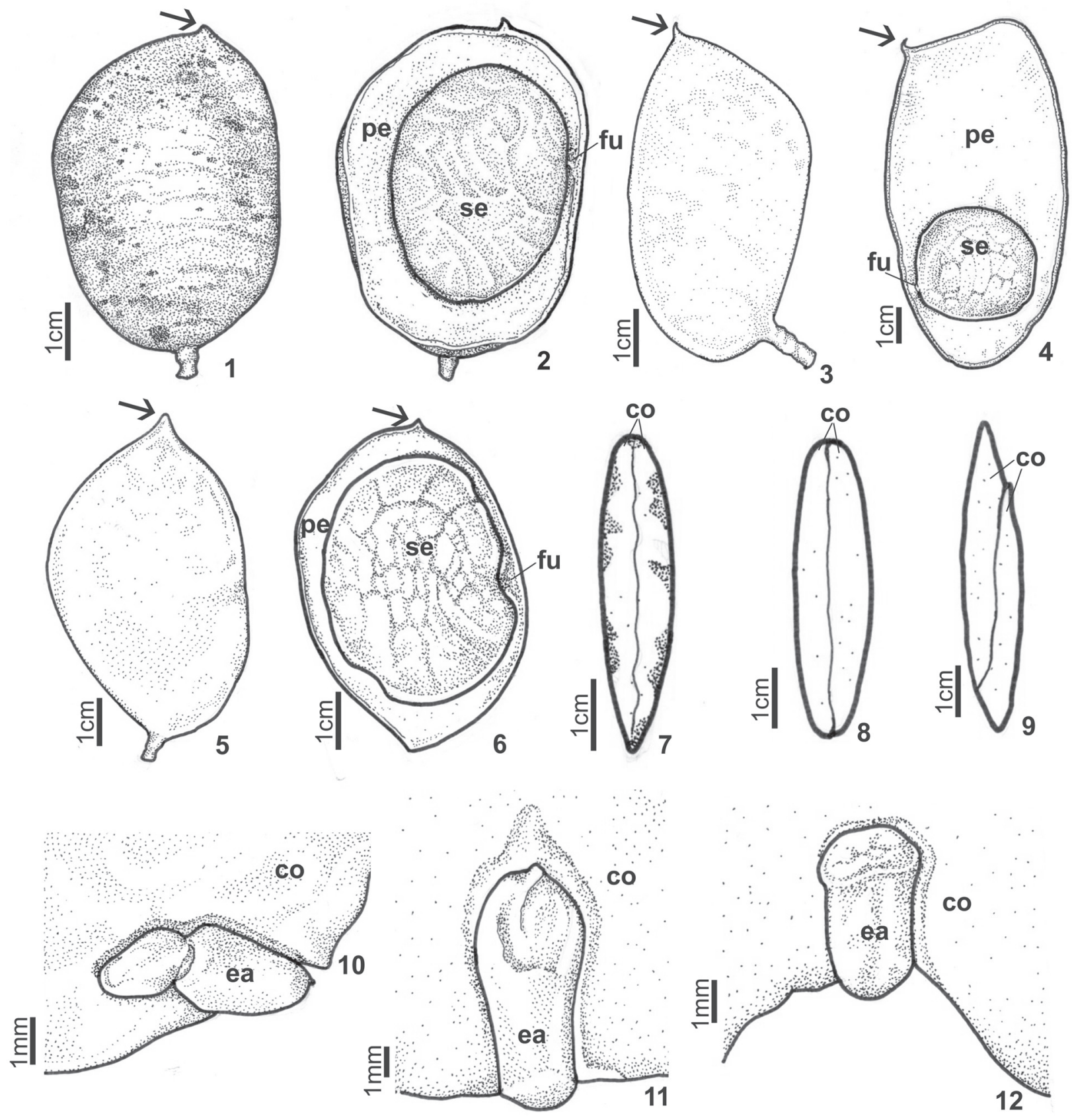

Figures 1-12. Fruits and seeds: Macrolobium acaciifolium (Benth.) Benth. (Fig. 1, 2, 7 and 10); Macrolobium bifolium (Aubl.) Pers. (Fig. 3, 4, 8 and 11); and Macrolobium pendulum Willd. ex Vogel (Fig. 5, 6, 9 and 12). Fig. 1-6: Entire fruits (odd numbered) and without a valve (even numbered); arrows indicate the apiculus. Fig. 7-9: Seeds in cross section. Fig. 10-12: Details of the embryo, showing the embryo axis. co - cotyledon; ea - embryo axis: fu - funiculus; pe - pericarp; se - seed.

between cotyledons (Fig. 32). The hypocotyl is cylindrical and glabrous. The epicotyl is cylindrical, dark-green and glabrous. The axillary buds are inconspicuous. The three first eophylls are alternate and bifoliolate, showing oblong to falcate leaflets, with oblique bases, obtuse to attenuate apices and entire margins; the pulvini and petioles are glabrous, and a pair of persistent stipules can be seen at the leaf base; a small pulvinule occurs at the base of each leaflet.

\section{Discussion}

According to Cowan (1953), the species of Macrolobium can present dehiscent fruits, as in M. acaciifolium, or indehiscent ones, as in M. bifolium and M. pendulum. The fruits of this genus are lateral flattened legumes, varying from suborbicular to oblong or spatulate (Cowan 1953). These forms were found for the fruits of M. acaciifolium 

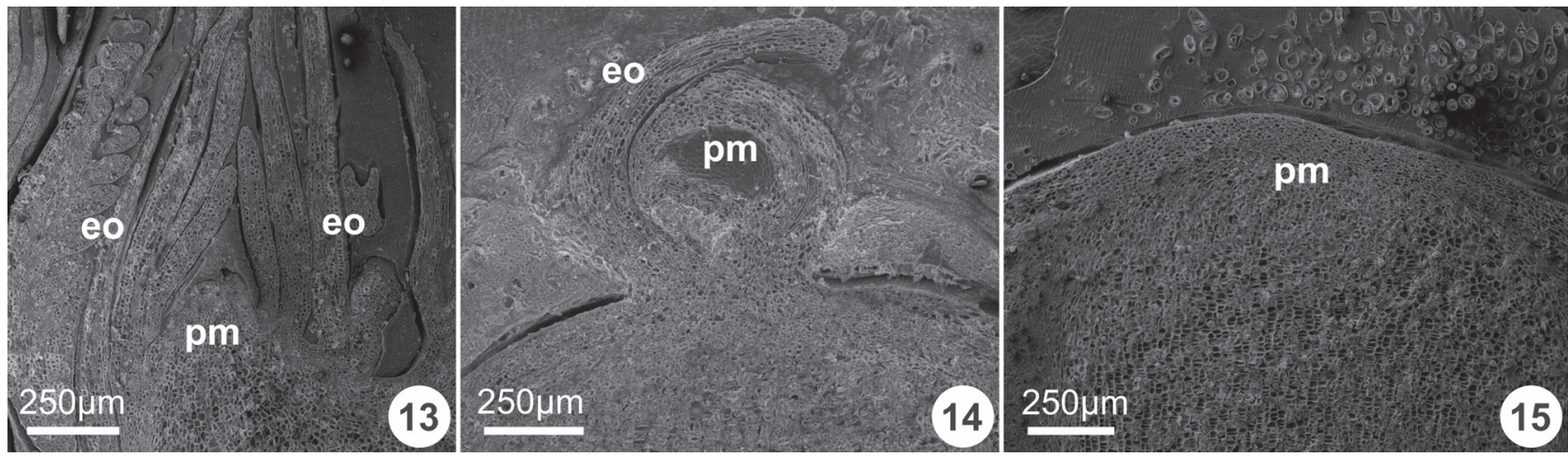

Figures 13-15. Plumule of Macrolobium. Fig. 13: Well differentiated plumule of Macrolobium acaciifolium (Benth.) Benth. Fig. 14: Moderately differentiated plumule of Macrolobium bifolium (Aubl.) Pers. Fig. 15: Undifferentiated plumule of Macrolobium pendulum Willd. ex Vogel.

eo - eophyll; pm - promeristem.

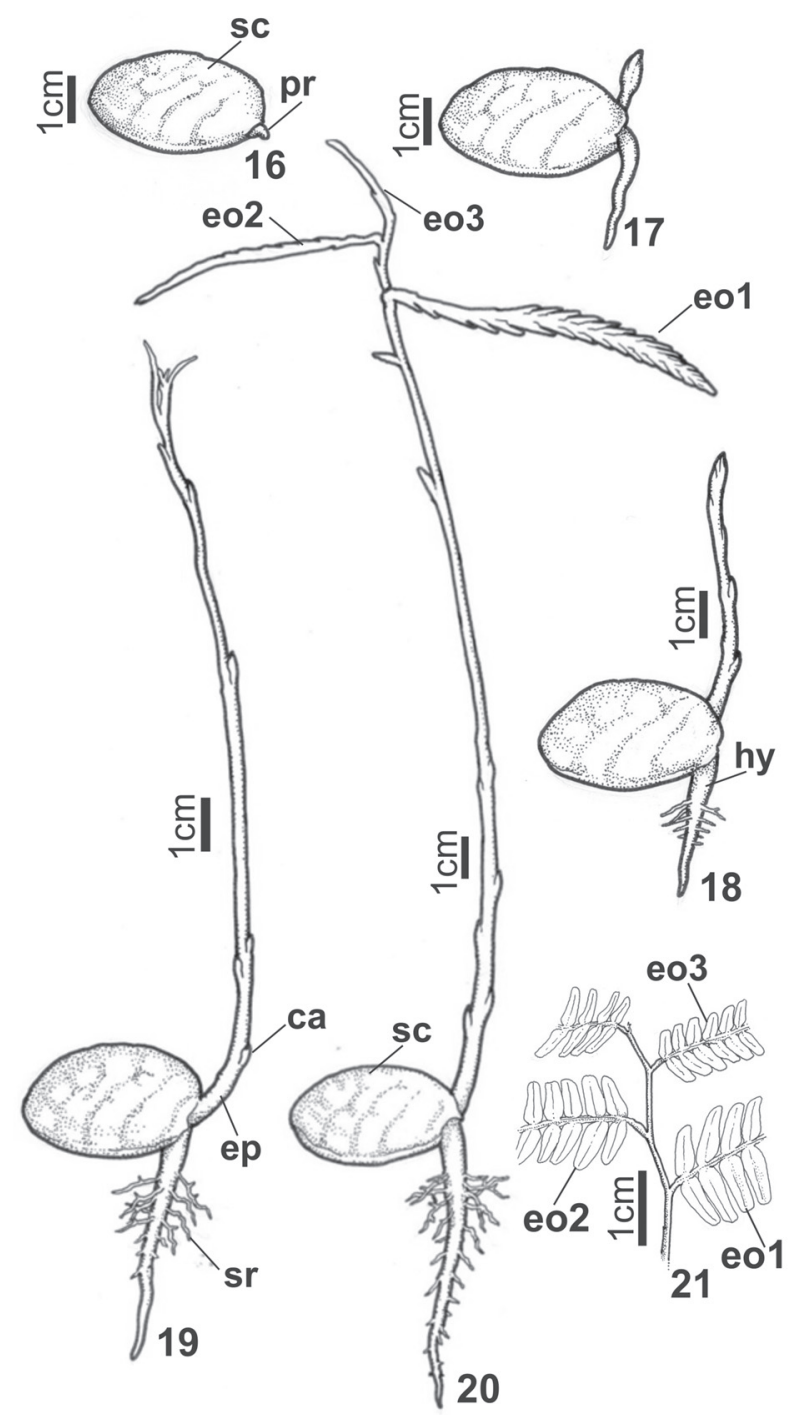

Figures 16-21. Seedlings and saplings of Macrolobium acaciifolium (Benth.) Benth. Fig. 16: Seedling at post-germination day 5. Fig. 17: Seedling at post-germination day 10. Fig. 18: Seedling at post-germination day 15. Fig. 19: Seedling at post-germination day 18. Fig. 20: Sapling at post-germination day 22. Fig. 21: Detail of leaf arrangement after complete eophyll expansion. ca - cataphyll; eo1-eo3 - sequence of eophylls; ep - epicotyl; hy - hypocotyl; $\mathrm{pr}$ - primary root; sc - seed coat; sr - secondary root. and M. bifolium, but not for M. pendulum, in which fruits were D-shaped, as was also reported by Kirkbride et al. (2003). The dehiscence, shape and pericarp traits, as well as other fruit characters, can help recognize the groups in Caesalpinioideae (Gunn 1991, Barroso et al. 1999).

In the present study, the measurements of fruits were consistent with those described for Macrolobium by Gunn (1991), Barroso et al. (1999) and Kirkbride et al. (2003). The analysis of the dimensions of the fruits demonstrated that M. bifolium had the largest fruits and M. acaciifolium had the smallest fruits.

Although the size and shape of the seeds were similar among the species studied, the values of seed length and thickness were highest for Macrolobium bifolium, as were the dimensions of the embryo axis. In M. bifolium and $M$. pendulum, the venation of seed coat is a notable trait that can be useful in identifying certain Macrolobium species; this feature was previously reported by Cowan (1953) in the last revision of the genus. Apparently, there are different patterns of seed coat venation, although only anatomical studies could describe and discuss those. For the seeds of M. acaciifolium, our data corroborate those of Cowan (1935), who described the crustose testa, and of Gunn (1991), who reported the intrusion of the testa into the corrugate cotyledons.

Gunn (1991) stated that the embryo axis is straight in 98\% of Caesalpinioideae genera. Macrolobium acaciifolium is one of the exceptions in the subfamily, presenting a clearly oblique embryo axis, as documented in the present work. The asymmetry of the cotyledons of $M$. pendulum, a state not shared by the other species studied, is noteworthy. Cowan (1953) and Gunn (1991) did not highlight this trait for Macrolobium species. According to Smith (1983) and Duke \& Polhill (1981), all of the Amherstieae (sensu Cowan \& Polhill 1981) have storage cotyledons, constituting exalbuminous seeds. Our data support that statement, because all three of the species studied showed fleshy cotyledons and only remains of the endosperm were found.

The evaluation of embryo structure of the studied species revealed many distinctive characters (see Tab. 2). 


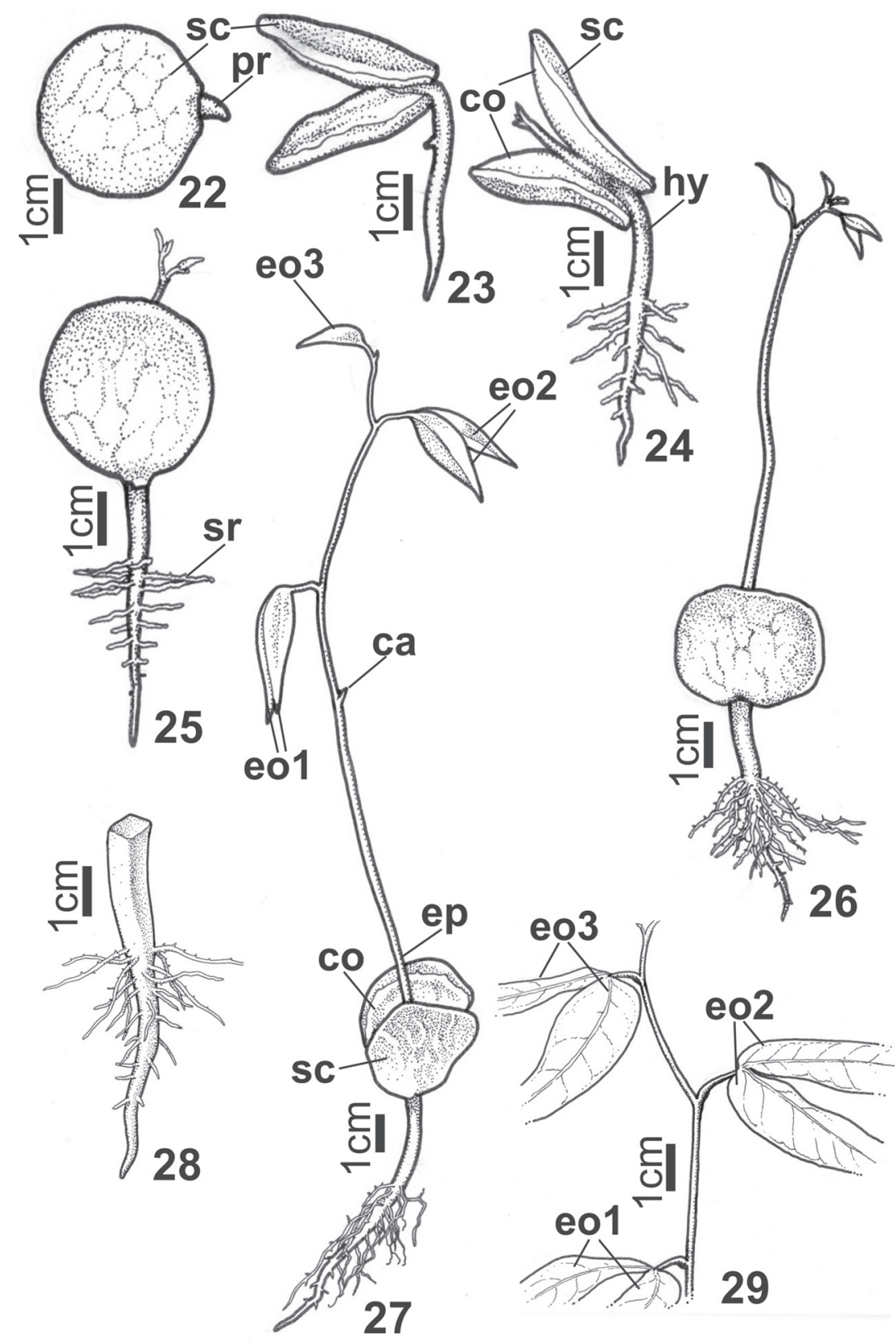

Figures 22-29. Seedlings and saplings of Macrolobium bifolium (Aubl.) Pers. Fig. 22: Seedling at post-germination day 5. Fig. 23: Seedling at post-germination day 7. Fig. 24: Seedling at post-germination day 10. Fig. 25: Seedling at post-germination day 12. Fig. 26: Seedling at post-germination day 17. Fig. 27: Sapling at post-germination day 25. Fig. 28: Detail of the hypocotyl showing the quadrangular cross-section. Fig. 29: Detail of leaf arrangement after complete eophyll expansion. ca - cataphyll; co - cotyledon; eo1-eo3 - sequence of eophylls; ep - epicotyl; hy - hypocotyl; pr - primary root; sc - seed coat; sr - secondary root.

Considering the embryo axis of Leguminosae species, the plumule is recognized as one of the most variable traits. In fact, the plumule development was a determinant in the separation of some groups in this family, such as Poecilanthe (Meireles \& Tozzi, 2008) and Copaifera (Gurgel, 2009), at the infrageneric and interspecific levels respectively. Caesalpinioideae presents all types of plumules, as observed in the work of Oliveira (1999b), in which the plumule was found to be well differentiated in Caesalpinia leiostachya (Benth.) Ducke; moderately differentiated in Cassia ferruginea
(Schrad.) Schrad. ex DC. and Peltophorum dubium (Spreng.) Taub.e; rudimentary in Dimorphandra mollis Benth.; and undifferentiated in Senna multijuga (Rich.) Irwin \& Barn. Gunn (1991) observed none of the variation reported here, reporting that the plumule of Macrolobium is rudimentary. In our results, the three Macrolobium species evaluated presented distinct patterns of plumule development, showing that detailed studies of this character can be relevant for species identification. These findings underscore the need for further studies of Macrolobium species in order to clarify 


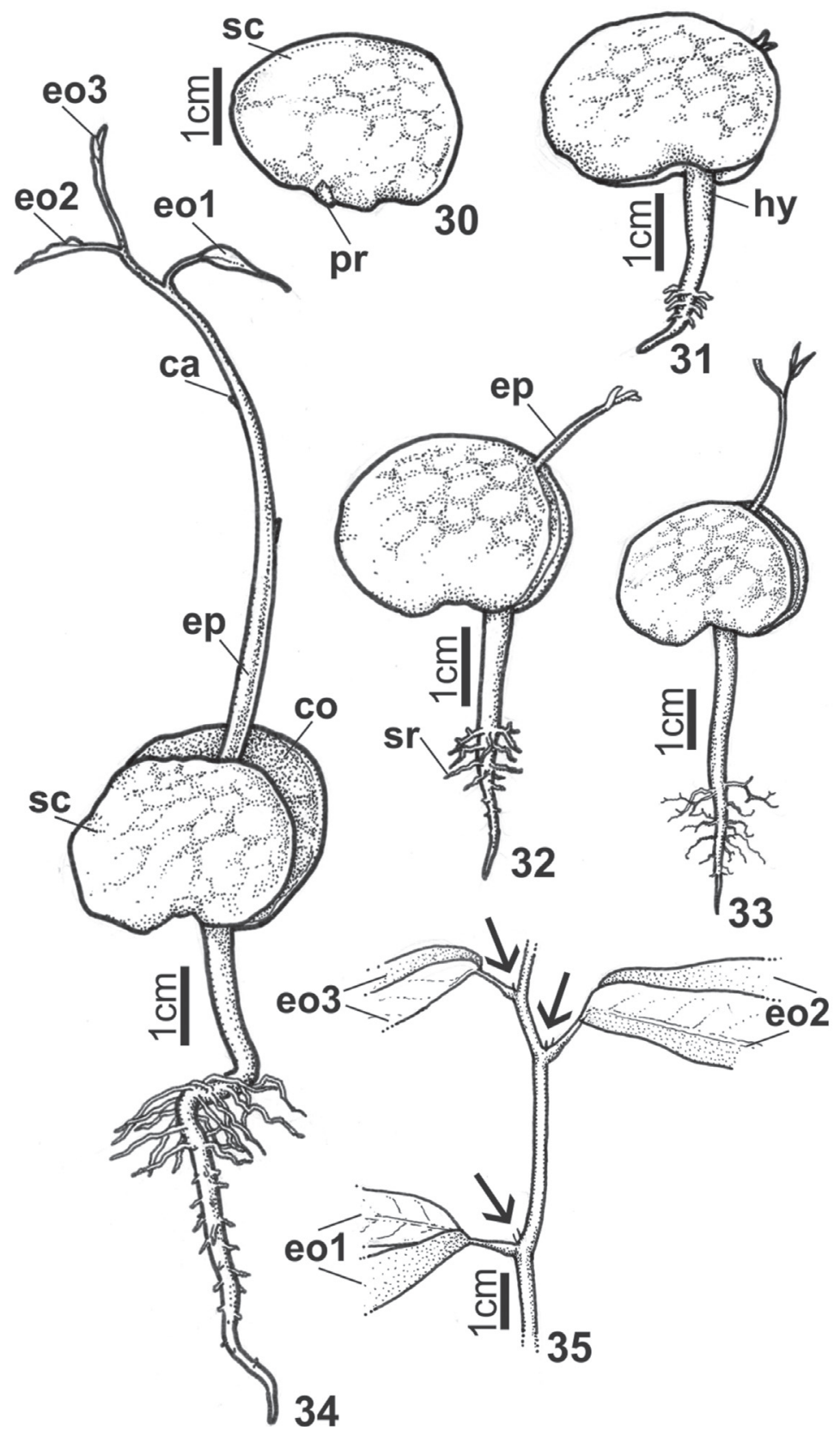

Figures 30-35. Seedlings and saplings of Macrolobium pendulum Willd. ex Vogel. Fig. 30: Seedling at post-germination day 5. Fig. 31: Seedling at post-germination day 10. Fig. 32: Seedling at post-germination day 15. Fig. 33: Seedling at post-germination day 20. Fig. 34: Sapling at post-germination day 25. Fig. 35: Detail of leaf arrangement after complete eophyll expansion (arrows indicate the persistent pairs of stipules).

ca - cataphyll; co - cotyledon; eo1-eo3 - sequence of eophylls; ep - epicotyl; hy - hypocotyl; pr - primary root; sc - seed coat; sr - secondary root.

aspects of circumscription and phylogeny, exploring the morphological diversity of the genus (Bruneau et al. 2001; Herendeen et al. 2003; Mackinder 2005).

Hypogeal germination, as we observed in Macrolobium acaciifolium, is considered a derived condition for Leguminosae (Moreira \& Moreira 1996). The CHR morphological type exhibited by $M$. acaciifolium was also reported by Silva et al. (1988) and Moreira \& Moreira (1996). Although Maia et al. (2005) classified the seedlings of this species as the phanerocotylar-hypogeal-reserve type, there seems to be some discrepancy regarding this point. Analyzing the figure of M. acaciifolium in Maia et al. (2005), we see that seeds were germinated within the indehiscent fruits, which opened during the process, thus inducing the misconception; in the referred figure, authors also drew the typical rugose seed coat of $M$. acaciifolium, confirming our interpretation. In the present study, Macrolobium bifolium and M. pendulum showed the PER morphological type, in agreement with the results of Gates (1951). Léonard (1957) made a brief description of the germination and 
Morphology of fruits, seeds, seedlings and saplings of three species of Macrolobium Schreb.

(Leguminosae, Caesalpinioideae) in the Brazilian Amazon floodplain

seedling type of $M$. bifolium, which is also in agreement with our data.

Some connections can be established between Leguminosae subfamilies and seedling or germination types. According to Gates (1951), seedlings of Caesalpinioideae and Mimosoideae are usually epigeal, differing from Papilionoideae, in which they are cryptocotylar or phanerocotylar. Duke \& Polhill (1981) stated that, in Caesalpinioideae alone, there are three groups with respect to the seedling type, in which the consistency and exposure of the cotyledons, as well as the structure of eophylls and metaphylls, can be variable. Gurgel et al. (2012) stated that Caesalpinioideae and Mimosoideae seedlings are considered epigeal with foliar cotyledons, and that hypogeal species with storage cotyledons predominate in the Papilionoideae. Oliveira (1999a) presented data for 30 leguminous tree species that corroborated the statements of Gates (1951), Duke \& Polhill (1981) and Gurgel et al. (2012). Examples of hypogeal species in Caesalpinioideae are very rare, and the results of the present study illustrate this pattern in Macrolobium acaciifolium.

When the ecological aspects are considered, the current knowledge about seedlings allows interesting evaluations to be performed. According to Lima (1989-90), the CHR morphofunctional type is normally found for species occurring in periodically flooded environments. This was confirmed by the Ressel et al. (2004), who identified CHR seedlings in species occurring in temporarily flooded areas; the authors also correlated CHR seedlings with the climax species. According to Felix-da-Silva et al. (2013), Macrolobium bifolium and M. pendulum (both having PER seedlings) occur only in flooded environments, as is the case for M. acaciifolium (which has CHR seedlings). It is possible that the occurrence in flooded environments was related to the presence of fleshy cotyledons, which supply the initial requirement of reserves for the establishment of the plant. It is also necessary to emphasize that, although producing phanerocotylar seedlings, $M$. bifolium and $M$. pendulum have seed coats that remain adhered to the abaxial face of the cotyledons, exposing only their adaxial face. Thus, the seed coat is partially responsible for the protection of cryptocotylar seedlings, exposing only part of the cotyledon surface.

The stipules observed for the studied taxa were persistent only in Macrolobium pendulum. Cowan (1953) stated that stipules are more frequently caducous in Macrolobium species but are persistent, which is a useful trait, in $M$. huberianum Ducke and M. pendulum. According to Cowan (1953), the persistence of stipules in M. pendulum is an important state distinguishing $M$. pendulum from its relatives M. palustre Ducke and M. savannarum R.S.Cowan when specimens are adults and not in the reproductive phase. Duke (1965) demonstrated that the presence or absence of stipules is a useful criterion for interspecific differentiation within a given genus. The occurrence of stipules in seedlings has also been described in other species of Caesalpinioideae, such as Apuleia leiocarpa (Vog.) Macbr., Senna macranthera (Collad.) H.S. Irwin \& Barneby (Finger et al. 1979) and Senna multijuga var. lindleyana (Amorim et al. 2008).

Typical of the legumes, the foliar nyctinasty is still scarcely described for seedlings of the Leguminosae family. The "forward-folding" nyctinasty found in the present study for the leaves of the Macrolobium species is probably related to the asymmetrical leave base, similar to what occurs in the Dalbergia clade (Lavin et al. 2001) and in the genus Acosmium (Rodrigues \& Tozzi, 2008).

As can be inferred from the data shown in Tab. 2, Macrolobium bifolium and $M$. pendulum are closely related species, sharing 10 character states, compared with only three shared by $M$. acaciifolium and M. bifolium, whereas $M$. acaciifolium and $M$. pendulum have no character states in common. These data corroborate the relationships within the genus Macrolobium described by Cowan (1953). According to that author, despite being in the same section (Vouapa), M. bifolium and M. pendulum are more closely related to each other than to M. acaciifolium, a species with more ancestral traits.

The data presented in this work underscore the relevance of detailed morphological studies (especially of seeds and seedlings) to understanding the ecological and phylogenetic aspects of leguminous species. Structural information about Macrolobium pendulum is provided here for the first time, contributing interesting knowledge for recognizing this species in the natural environment.

\section{Acknowledgments}

We are grateful to Tarcymara Garcia, for the analysis of the scanning electron microscopy, and to João Silveira, for the drawings. This study received financial support from the Brazilian Conselho Nacional de Desenvolvimento Científico e Tecnológico (CNPq, National Council for Scientific and Technological Development; grant to the first author via the Programa de Capacitação em Taxonomia, [PROTAX, Taxonomy Training Program]) and Coordenação de Aperfeiçoamento de Pessoal de Nivel Superior (CAPES, Office for the Advancement of Higher Education; Grant no. PNADB 922/2010).

\section{References}

Aguiar, M.O. \& Mendonça, M.S. 2000. Aspectos morfológicos de plântulas de açaí (Euterpe precatoria Mart.). Boletim do Museu Paraense Emílio Goeldi, Botânica 16: 53-62.

Amorim, I.B.; Davide, A.C.; Ferreira, R.A. \& Chaves, M.M.F. 2008. Morfologia de frutos, sementes, plântulas e mudas de Senna multijuga var. lindleyana (Gardner) H. S. Irwin \& Barneby - Leguminosae Caesalpinioideae. Revista Brasileira de Botânica 31: 507-516.

Barroso, G.M.; Amorim, M.P.; Peixoto, A.L. \& Ichaso, C.L.F. 1999. Frutos e sementes: morfologia aplicada à sistemática de dicotiledôneas. Viçosa, Editora UFV.

Baudet, J.C. 1974. Signification taxonomique des caractères blastogèniques dans la tribu des Papilionaceae - Phaseoleae. Bulletin du Jardin Botanique National de Belgique 44: 259-293. 
Breteler, F.J. 1995. The boundary between Amherstieae and Detarieae (Caesalpinioideae). Pp. 53-62. In: Crisp, M.D. \& Doyle, J.J. (Eds.). Advances in legume systematics. Part 7. Kew, Royal Botanic Gardens.

Bruneau, A.; Breteler, F.J.; Wieringa, J.J.; Gervais, G.Y.F. \& Forest, F. 2000. Phylogenetic relationships in tribes Macrolobieae and Detarieae as inferred from chloroplast $t r n \mathrm{~L}$ intron sequences. Pp.121-149. In: Herendeen, P.S. \& Bruneau, A. (Eds.). Advances in legume systematics. Part 9. Kew, Royal Botanic Gardens.

Bruneau, A.; Forest, F.; Herendeen, P.S.; Klitgaard, B.B. \& Lewis, G.P. 2001. Phylogenetic relationships in Caesalpinioideae (Leguminosae) as inferred from chloroplast $\operatorname{trn} \mathrm{L}$ intron sequences. Systematic Botany 26: $487-514$

Camargo, J.B.C; Ferraz, I.D.K; Mesquita, M.R; Santos, B.A. \& Brum, H.D. 2008. Guia de propágulos \& plântulas da Amazônia. v.1. Manaus, INPA.

Cowan, R.S. 1953. A taxonomic revision of the genus Macrolobium (Leguminosae - Caesalpinioideae). Memoirs of the New York Botanical Garden 8: 257-342

Cowan, R.S. \& Polhill, R.M. 1981. Amherstieae Benth. emend. J. Léon. (1957). Pp.135-142. In: Polhill, R.M. \& Raven, P.H. (Eds.). Advances in legumes Systematics. Part 1. Kew, Royal Botanic Gardens.

De la Estrella, M.; Devesa, J.A. \& Wieiringa, J.J. 2012. A morphological re-evaluation of the taxonomic status of the genus Pellegriniodendron (Harms) J. Léonard (Leguminosae - Caesalpinioideae - Detarieae) and its inclusion in Gilbertiodendron J. Léonard. South African Journal of Botany 78: 257-265.

Ducke, A. 1949. Notas sobre a Flora Neotrópica - II. As Leguminosas da Amazônia brasileira. Boletim Técnico do Instituto Agronômico do Norte 18:1-248.

Duke, J.A. 1965. Keys for identification of seedlings of some prominent Woody species in eight forest types in Puerto Rico. Annals of the Missouri Botanical Garden 52: 314-350.

Duke, J.A. \& Polhill, R.M. 1981. Seedlings of Leguminosae. Pp.941-949. In: Polhill, R.M. \& Raven, P.H. (Eds.). Advances in legumes Systematics. Part 2. Kew, Royal Botanic Gardens.

Félix-da-Silva, M.M.; Bastos, M.N.C.; Gurgel, E.S.C. 2013. Macrolobium Schreb. (Leguminosae, Caesalpinioideae) na Floresta Nacional de Caxiuanã, Pará, Brasil. Boletim do Museu Paraense Emílio Goeldi, Ciências Naturais 8: 75-93.

Finger, Z.; Ramalho, R.S.; Brandi, R.M. \& Cândido, J.F. 1979. Estudos dendrológicos da regeneração natural na microrregião de Viçosa, MG. I. Identificação e descrição de algumas espécies. Revista Árvore 3:94-119.

Gama, J.R.V.; Botelho, S.A.; Bentes-Gama, M.M. \& Scolforo, J.R.S. 2003. Estrutura e potencial futuro de utilização da regeneração natural de Floresta de várzea alta no Município de Afuá, estado do Pará. Ciência Florestal 13: 71-82

Garwood, N.C. 1995. Studies in Annonaceae. XX. Morphology and ecology of seedlings, fruits and seeds of selected Panamanian species. Botanische Jahrbücher für Systematik 117: 1-152.

Garwood, N.C. 1996. Functional morphology of tropical tree seedlings. Pp. 59-129. In: Swaine, M.D. (Ed.). The ecology of tropical forest tree seedlings. Paris, Unesco.

Gates, R.R. 1951. Epigeal germination in the Leguminosae. Botanical Gazette 113: 151-157.

Gunn, C.R. 1981. Seeds of Leguminosae. Pp. 913-925. In: Polhill, R.M. \& Raven, P.H. (Eds.). Advances in legume systematics. Part 2. Kew, Royal Botanic Garden.

Gunn, C.R. 1991. Fruits and seeds of genera in the subfamily Caesalpinioideae (Fabaceae). Technical Bulletin, United States Department of Agriculture 1755: 1-408.

Gurgel, E.S.C. 2009. Morfoanatomia, perfil químico e atividade alelopática de três espécies de Copaifera L. (Leguminosae Caesalpinioideae) nativas da Amazônia. PhD dissertation. Manaus, Instituto Nacional de Pesquisas da Amazônia, Universidade Federal do Amazonas.

Gurgel, E.S.C.; Santos, J.U.M.; Lucas, F.C.A. \& Bastos, M.N.C. 2012. Morfologia de plântulas de Leguminosae e o potencial sistemático. Rodriguésia 63: 65-73.
Gurgel, E.S.C.; Silva, M.F. \& Carreira, L.M.M. 2002. Morfologia do fruto, da semente e da plântula de Calopogonium mucunoides Desv. e Dipteryx odorata (Aubl.) Willd. (Leguminosae, Papilionoideae). Boletim do Museu Paraense Emílio Goeldi, Botânica 18: 37-60.

Harris, J.G. \& Harris, M.W. 2001. Plant identification terminology: an illustrated glossary. 2nd.ed. Spring Lake, Spring Lake Publishing.

Herendeen, P.S.; Bruneau, A. \& Lewis, G.P. 2003. Phylogenetic relationships in caesalpinioid legumes: a preliminary analysis based on morphological and molecular data. Pp.37-62. In: Klitgaard, B.B. \& Bruneau, A. (Eds.). Advances in Legumes Systematics. Part 10. Kew, Royal Botanic Gardens.

Jardim, M.A.G. \& Vieira, I.C.G. 2001. Composição florística e estrutura de uma floresta de várzea do estuário Amazônico, Ilha do Combu, estado do Pará. Brasil. Boletim do Museu Paraense Emílio Goeldi, Botânica 17: 333-354.

Kirkbride, J.H.; Gunn, C.R.; Weitzman, A. L. \& Dallwitz, M.J. 2003. Legume (Fabaceae) fruits and seeds. Version 2.0 USDA, ARS. Available from: http://nt.ars-grin.gov/seedsfruits/keys/fabaceae/index.cfm. Cited 2014 Feb 21.

Lavin, M.; Pennington, R.T.; Klitgaard, B.B.; Sprent, J.I.; Lima, H.C. \& Gasson, P.E. 2001. The dalbergioid legumes (Fabaceae): delimitation of a paleotropical monophyletic clade. American Journal of Botany 88: 503-533.

Léonard, J. 1957. Genera des Cynometreae et des Amherstieae africaines (Léguminosae-Caesalpinioideae). Essai de blastogenie appliqué à la systématique. Mémoires de l'Académie Royale de Sciences. Lettres et Beaux-Arts de Belgique. Classe des Sciences 8: 1-314.

Lewis, G.; Schrire, B.; Mackinder, B. \& Lock, M. 2005. Legumes of the world. Kew, Royal Botanic Gardens.

Lima, H.C. 1989-90. Tribo Dalbergieae (Leguminosae Papilionoideae) - Morfologia de frutos, sementes e plântulas e sua aplicação na sistemática. Arquivos do Jardim Botânico do Rio de Janeiro 30: 1-42.

López, J.; Devesa, J.A.; Ruiz, T. \& Ortega-Olivencia, A. 1998. Seedling morphology in Genisteae (Fabaceae) from south-west Spain. Botanical Journal of the Linnean Society 127: 229-250.

Mackinder, B. 2005. Tribe Detarieae. Pp. 69-109. In: Lewis, G.P.; Schrire, B.; Mackinder, B. \& Lock, M. (Eds.). Legumes of the World. Kew Royal Botanic Gardens.

Maia, A.L; Maia, S. \& Parolin, P. 2005. Seedling morphology of non-pioneer trees in central Amazonian várzea floodplain forests. Ecotropica 11: 1-8.

Martins-da-Silva, R.C.V. \& Lima, H.C. 2013. Macrolobium in Lista de Espécies da Flora do Brasil. Rio de Janeiro, Jardim Botânico do Rio de Janeiro. Available from: http://floradobrasil.jbrj.gov.br/jabot/ floradobrasil/FB23066. Cited 2014 Feb 21.

Maués, B.A.R.; Jardim, M.A.G.; Batista, F.J.; Medeiros, T.D.S. \& Quaresma, A.C. 2011. Composição florística e estrutura do estrato inferior da floresta de várzea na Área de Proteção Ambiental Ilha do Combu, município de Belém, estado do Pará. Revista Árvore 35: 669-677.

Meireles, J.E. \& Tozzi, A.M.A. 2008. Seed and embryo morphology of Poecilanthe (Fabaceae, Papilionoideae, Brongniartieae). Botanical Journal of the Linnean Society 158: 249-256.

Moreira, F.M.S. \& Moreira, F.W. 1996. Características da germinação de sementes de 64 espécies de leguminosas florestais nativas da Amazônia, em condições de viveiro. Acta Amazonica 26: 3-16.

Moreira-Coneglian, I.R. \& Oliveira, D.M.T. 2006. Anatomia comparada dos limbos cotiledonares e eofilares de dez espécies de Caesalpinioideae (Fabaceae). Revista Brasileira de Botânica 29: 193-207.

Oliveira, D.M.T. 1999a. Morfologia de plântulas e plantas jovens de 30 espécies arbóreas de Leguminosae. Acta Botanica Brasilica 13: 263-269.

Oliveira, D.M.T. 1999b. Morfo-anatomia do embrião de leguminosas arbóreas nativas. Revista Brasileira de Botânica 22: 413-427.

Oliveira, D.M.T. 2001. Morfologia comparada de plântulas e plantas jovens de leguminosas arbóreas nativas: espécies de Phaseoleae, Sophoreae, Swartzieae e Tephrosieae. Revista Brasileira de Botânica 24: 85-97.

Oliveira, E.C. \& Pereira, T.S. 1984. Morfologia dos frutos alados em Leguminosae-Caesalpinioideae - Martiodendron Gleason, Peltophorum (Vogel) Walpers, Sclerolobium Vogel, Tachigalia Aublet e Schizolobium Vogel. Rodriguésia 36: 35-42. 
Morphology of fruits, seeds, seedlings and saplings of three species of Macrolobium Schreb.

(Leguminosae, Caesalpinioideae) in the Brazilian Amazon floodplain

Parra, P. 1984. Estudio de la morfologia externa de plántulas de Calliandra gracillis, Mimosa albida, Mimosa arenosa, Mimosa camporum y Mimosa tenuiflora. Revista de la Facultad de Agronomía (Maracay) 13:311-350.

Polhill, R.M. 1994. Classification of the Leguminosae. Pp. 35-56. In: Bisby, F.A.; Buckingham, J. \& Harborne, J.B. (Eds.). Phytochemical dictionary of the Leguminosae. London, Chapman and Hall.

Radford, A.E.; Dickson, W.C.; Massey, J.R. \& Bell, C.R. 1974. Vascular plant systematics. New York, Harper \& Row Publishers

Ramos, M.B.P. \& Ferraz, I.D.K. 2008. Estudos morfológicos de frutos, sementes e plântulas de Enterolobium schomburgkii Benth. (Leguminosae - Mimosoideae). Revista Brasileira de Botânica 31: 227-235.

Ressel, K.; Guilherme, F.A.G.; Schiavini, I. \& Oliveira, P.E. 2004. Ecologia morfofuncional de plântulas de espécies arbóreas da Estação Ecológica do Panga, Uberlândia, Minas Gerais. Revista Brasileira de Botânica 27: 311-323.

Ricardi, M. 1996. Morfología de los cotiledones de plántulas de algunas familias o géneros presentes en Venezuela como fuente de caracteres para su determinación. Plantula 1: 1-11.

Ricardi, M. 1999a. Morfología de plántulas de árboles de un bosque Montano bajo. Plantula 2: 1-72.

Ricardi, M. 1999b. Morfología de plántulas de bejucos de un bosque Montano bajo. Plantula 1: 13-54

Robards, A.W. 1978. An introduction to techniques for scanning electron microscopy of plant cells. Pp. 343-415. In: Hall, J.L. (Ed.). Electron Microscopy and Cytochemistry of Plant Cells. New York, Elsevier.

Rodrigues, L.M.B.; Lira, A.U.S.; Santos, F.A. \& Jardim, M.A.G. 2006. Composição florística e usos das espécies vegetais de dois ambientes de floresta de várzea. Revista Brasileira de Farmácia 87: 45-48.
Rodrigues, R.S.; Hirt, A.P.M. \& Flores, A.S. 2012. Morfologia de plântulas das espécies de Rhynchosia (Leguminosae, Papilionoideae) de Roraima, Brasil. Acta Botanica Brasilica 26: 585-592.

Rodrigues, R.S. \& Tozzi, A.M.G.A. 2007a. Morfologia de plântulas do clado Vatairea (Leguminosae, Papilionoideae). Rodriguésia 58: 221-229.

Rodrigues, R.S. \& Tozzi, A.M.G.A. 2007b. Morfologia de cinco leguminosas genistóides arbóreas do Brasil (Leguminosae- Papilionoideae). Acta Botanica Brasilica 21: 599-607.

Rodrigues, R.S. \& Tozzi, A.M.G.A. 2008. Systematic relevance of seedling morphology in Acosmium, Guianodendron, and Leptolobium (Leguminosae, Papilionoideae). Brittonia 60: 287-296.

Schöngart, J.; Piedade, M.T.F.; Wittmann, F.; Junk, W.J. \& Worbes, M. 2005. Wood growth patterns of Macrolobium acaciifolium (Benth.) Benth. (Fabaceae) in Amazonian black-water and white-water floodplain forests. Oecologia 145: 454-461.

Silva, C.A.R. \& Sampaio, L.S. 1998. Speciation of phosphorus in a tidal floodplain forest in the Amazon estuary. Mangrove and Salt Marshes 2: 51-57.

Silva, M.F.; Goldman, G.H.; Magalhães, F.M. \& Moreira, F.W. 1988 Germinação natural de 10 espécies arbóreas da Amazônia - I. Acta Amazonica 18: 9-26.

Smith, D.L. 1983. Cotyledon anatomy in the Leguminosae. Botanical Journal of the Linnean Society 86: 325-355.

Vieira, I.C.G., Galvão, N. \& Rosa, N.A. 1996. Caracterização morfológica de frutos e germinação de sementes de espécies arbóreas nativas na Amazônia. Boletim do Museu Paraense Emilio Goeldi, Botânica 16: 271-288. 